EISSN: $2706-7947$ ISSN: 2077- 4613

DOI: 10.36632/mejas/2021.11.1.7

Journal homepage: www.curresweb.com

Pages: 63-75

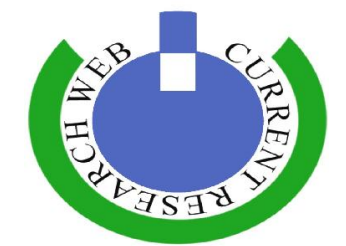

\title{
Assessment of Automatic Pulse Drip Irrigation Technique on Water Application Efficiency and Water Productivity of Cucumber Crop
}

\author{
El-Shafie A.F. ${ }^{1}$, M.A. Marwa ${ }^{1}$, O.M. Dewedar ${ }^{1}$, A.A. Ghoname $^{2}$ and R.E. Abdelraouf $^{1}$ \\ ${ }^{1}$ Water Relations and Field Irrigation Department, Agricultural and Biological Division, National \\ Research Centre, 33 EL Bohouth St., Dokki, Giza, Egypt, Postal Code: 12622. \\ ${ }^{2}$ Vegetable Research Dept., Agricultural and Biological Division, National Research Centre, 33 EL \\ Bohouth St., Dokki, Giza, Egypt, Postal Code: 12622.
}

Received: 15 December 2020 Accepted: 10 January $2021 \quad$ Published: 30 January 2021

\begin{abstract}
There are more implications for using controlling methods of scheduling irrigation and pulse drip irrigation to improve soil moisture distribution, water application efficiency and yield in greenhouse conditions. The main goals of this research paper are to maximize water application efficiency and improve crop and water productivity of cucumber crop, using manual and automatic control for scheduling irrigation and three pulses treatments (Ps6: 6 pulses/day, Ps3: 3 pulses/day and Ps 1: 1 pulse as a control) using drip irrigation system under greenhouses conditions. To achieve the goals of this study, two field trials were conducted in greenhouse during 2017/2018 and 2018/2019 seasons at the research farm station of National Research Centre, Al-Nubariya Region, Al-Buhayrah, Egypt. The results indicated that, the automatic control scheduling irrigation under all pulses drip irrigation gave the superior in soil moisture content, water application efficiency, yield and water productivity. The highest values of soil moisture content were under 6 pulses for irrigation per day and the lowest values were at continuous irrigation "Ps1" with both irrigation scheduling controlling methods. The highest water application efficiency values were 97 and $96.3 \%$ under automatic irrigation and 6 pulses/day treatment, the lowest values were 89 and $86 \%$ under manual irrigation and 1 pulse/day, for the two growing seasons, respectively. The same trend is found between yield and water productivity of cucumber crop. Generally the highest values of yield were (153.8 and 152.1 ton ha $\left.{ }^{-1}\right)$, and the water productivity were $\left(25.67\right.$ and $\left.24.9 \mathrm{~kg} \mathrm{~m}^{-3}\right)$ under automatic control of scheduling irrigation with 6 pulses/day, for the two growing seasons, respectively. Finally, the use of pulse irrigation with automatic control is preferred as an alternative to manual control of scheduling irrigation.
\end{abstract}

Keywords: Automatic irrigation, pulse irrigation, water productivity, cucumber and greenhouses

\section{Introduction}

Water is one of the most important elements in agricultural projects, including food security, industrial development, housing and urban expansion and all other aspects of human life activities. Water resources are a limiting factor for the agricultural production, and saving water becomes clearly a necessity. Therefore, irrigation technologies appear to play a major role in supporting agro-economy. In this light, water scarcity, appears to be a real big problem of the world economy in the near future. Therefore, water consumption, in all life activities, should be optimized and water be treated as a rare and important commodity (Marwa et al., 2017). A number of approaches could be followed to maximize the water use efficiency, some of which are related to the soil, some are related to the plant while others belong to the water supplied to the plant (Abdelraouf and El Habbasha, 2014, Wahba et al., 2016). Therefore, the most important goals of any agricultural project are optimizing the water use in agriculture and increasing the irrigation efficiency to save the water. Accordingly, improving water

Corresponding Author: R.E. Abdelraouf, Water Relations and Field Irrigation Department, National Research Centre, 33 EL Buhouth St., Dokki, Giza, Egypt, Postal Code: 12622.

E-mail: abdelrouf2000@yahoo.com 
productivity with higher yields is inevitable (El-Safie et al., 2018). Soil evaporation is a very important component of the water balance in natural and cultivated systems. It is estimated that $50-70 \%$ of the annual precipitation returns to the atmosphere without any benefit to biomass production (Jalota and Prihar, 1990).

The reduction of soil evaporation is essential to increase the water use efficiency of agricultural crops (Sarkar et al., 2007 and Hou et al., 2010).

However, using the automatic irrigation with developing the scheduling irrigation methods very accurately, providing different cultivated crops with their exact requirements of water at the correct time for the plant and it is a suitable tool to improve water use efficiency (Lozano et al., 2020 and Smarsly, 2013). Also, if these methods are scheduled and adjusted to give, exactly, the estimated amount of water appropriate to the plant needs within the different growth stages; it would save water and give the plant the precise essential needs of water and nutrients for its optimal growth and production (Luquet et al., 2005). Moreover, it will consume the minimum water, fertilizers, energy and labor as well. Also, it will render the plant avoid any stress of water deficiency (Marwa et al., 2017). Under scheduling irrigation, the irrigation water can be divided into various times, with a break in between (Maller et al., 2019).

The application of short-pulse irrigation resulted in a decrease in the uniformity of water distribution and the application efficiency, this is due to the water is added at one time, with more of deep percolation (Lozano et al., 2020). The benefits of pulse irrigation method, such as reducing surface soil water evaporation, decreasing fertilizers leaching, enhancing yield and so on, have been documented by different researchers . Drip irrigation with over irrigation, valuable nutrients may be leached out of the root zone and become unavailable for the plants, while contaminating the groundwater (Zin El-Abedin, 2006). The use of pulse irrigation provides the water content that is able to keep the quality of the crop and the application of pulse irrigation gives a good high yield index and a low root production index (Zamora et al., 2019).

Cucumber is one of the vegetable crops most used on the table, which is grown in greenhouses in Egypt. Fresh fruits are greatly affected by decrease amount of water, so it is preferable to schedule the irrigation during the growth season (Abdelraouf et al., 2020).

Therefore the main goals of this study are to maximize water application efficiency and improve crop and water productivity of cucumber crop, using automatic pulse drip irrigation under greenhouses conditions.

\section{Materials and Methods}

\subsection{Location and climate of experimental site}

The field experiments were conducted during 2017/2018 and 2018/2019 seasons at the research farm station of National Research Centre (NRC) (latitude 30o 30' 1.4"N, longitude 30o19' 10.9" E, and $21 \mathrm{~m}+$ MSL (mean sea level) at Al-Nubariya Region, Al-Buhayrah Governorate, Egypt. The experimental area has an arid climate with cool winters and hot dry summer. The data of average temperature, relative humidity and wind speed were obtained from the meteorological data of the Central Laboratory for Agricultural Climate (CLAC), Agricultural Research Centre for El-Nubaryia region, as shown in Table (1).

\subsection{Physical and chemical properties of soil and irrigation water}

Irrigation water source was an irrigation channel passing through the experimental area, with an average $\mathrm{pH}$ of 7.36 and $0.42 \mathrm{dS} \mathrm{m}^{-1}$ as electrical conductivity (EC). The main physical and chemical properties of the soil are shown in Table (2). 
Table 1: The data of average temperature, relative humidity and wind speed were obtained from the local weather station at El-Nubaryia farm.

\begin{tabular}{|c|c|c|c|c|c|c|c|c|}
\hline \multicolumn{9}{|c|}{ Climatic mean values, $2017 / 2018$} \\
\hline Months & SRAD & $\mathbf{T}_{\text {MAX }}$ & $\mathbf{T}_{\text {MIN }}$ & RAIN & WIND & $\mathbf{T}_{\text {DEW }}$ & $\mathbf{T}_{\text {Mean }}$ & RH \\
\hline November & 13.98 & 24.25 & 12.23 & 0.00 & 3.42 & 8.98 & 17.35 & 58.36 \\
\hline December & 10.36 & 21.29 & 10.32 & 0.00 & 3.64 & 7.92 & 14.92 & 63.50 \\
\hline January & 12.38 & 17.61 & 5.97 & 0.00 & 3.67 & 3.54 & 10.92 & 61.22 \\
\hline February & 15.21 & 20.01 & 6.71 & 0.00 & 3.51 & 4.94 & 12.41 & 60.56 \\
\hline March & 19.80 & 24.05 & 10.13 & 0.00 & 4.21 & 5.95 & 16.27 & 51.50 \\
\hline \multicolumn{9}{|c|}{ Climatic mean values, $2018 / 2019$} \\
\hline November & 12.45 & 24.38 & 14.35 & 19.12 & 4.13 & 6.88 & 18.73 & 69.17 \\
\hline December & 10.55 & 20.35 & 10.52 & 31.05 & 5.13 & 6.12 & 14.77 & 69.83 \\
\hline January & 11.40 & 18.82 & 8.70 & 34.48 & 5.33 & 5.95 & 13.07 & 67.83 \\
\hline February & 14.03 & 19.73 & 8.98 & 17.60 & 5.67 & 6.88 & 13.98 & 67.00 \\
\hline March & 17.95 & 21.55 & 10.70 & 9.63 & 6.12 & 7.68 & 15.90 & 61.00 \\
\hline
\end{tabular}

SRAD: $\left(\mathrm{MJ} / \mathrm{m}^{\wedge} 2 /\right.$ day, $\mathrm{T}_{\mathrm{MAX}}$ : Maximum Air Temperature (degrees $\left.\mathrm{C}\right), \mathbf{T}_{\text {MIN }}$ : Minimum Air Temperature (degrees $\left.\mathrm{C}\right)$,

RAIN: Average Precipitation (mm/day), WIND: Wind Speed (m/s), T

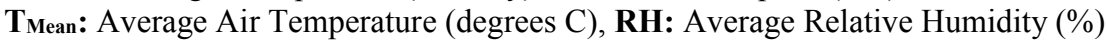

Table 2: Physical and chemical properties of the soil of the experimental area.

\begin{tabular}{lccc}
\hline Physical properties & & & \\
\hline Soil layer depth (cm) & $\mathbf{0 - 1 5}$ & $\mathbf{1 5 - 3 0}$ & $\mathbf{3 0 - 4 5}$ \\
Texture & Sandy & Sandy & Sandy \\
\hline Course sand (\%) & 48.62 & 54.77 & 42.64 \\
Fine sand (\%) & 48.80 & 41.55 & 53.46 \\
Silt+ clay (\%) & 2.58 & 3.68 & 3.90 \\
Bulk density (t m-3) & 1.68 & 1.66 & 1.65 \\
\hline & & \\
EC1:5 (dS m-1) & 0.46 & 0.50 & 0.65 \\
pH (1:2.5) & 8.51 & 8.50 & 8.82 \\
Total CaCO3 (\%) & 7.11 & 2.44 & 4.65 \\
\hline
\end{tabular}

\subsection{Experimental design}

Experimental design and treatments were arranged in a split plot design with three replications. Irrigation scheduling method [Manual control "MC" and Automatic control "AC"] were used in main plots and pulse drip irrigation [Ps6: 6 pulses/day, Ps3: 3 pulses/day and Ps1: 1 pulse/day as a control (continuous drip irrigation)] and were used in sub main plots as shown in Figure (1).

\subsection{Estimation the seasonal irrigation water for cucumber}

Seasonal irrigation water was estimated according to the meteorological data of the Central Laboratory for Agricultural Climate (CLAC), Agricultural Research Center, Dokki, Egypt depending on Penman-Monteith equation. Seasonal irrigation water requirement for cucumber Crop were $6000 \mathrm{~m}^{3}$ $\mathrm{ha}^{-1}$ for season $2017 / 18$ and $6100 \mathrm{~m}^{3} \mathrm{ha}^{-1}$ for season 2018/19. Daily irrigation water was calculated by following equation (1) for two seasons 2018 and 2019 under drip irrigation system:

$\mathrm{IRg}=\left[\left(\mathrm{ET}_{\mathrm{O}} \times \mathrm{Kc} \times \mathrm{Kr}\right) / \mathrm{Ei}\right]-\mathrm{R}+\mathrm{LR}$

Where: $\mathrm{IRg}=$ Gross irrigation requirements, $\mathrm{mm} /$ day, $\mathrm{ET}_{\mathrm{O}}=$ Reference evapotranspiration, $\mathrm{mm} /$ day, $\mathrm{Kc}=$ Crop factor (Allen et al., 2005), $\mathrm{Kr}=$ Ground cover reduction factor, $\mathrm{Ei}=$ Irrigation efficiency, $\%, \mathrm{R}=$ Water received by plant from sources other than irrigation, $\mathrm{mm}$ (for example rainfall), $\mathrm{LR}=$ Amount of water required for the leaching of salts, $\mathrm{mm}$. Gross irrigation requirements was converted from $\mathrm{mm} / \mathrm{ha} /$ day to $\mathrm{m}^{3} / \mathrm{ha} /$ day (Savva and Frenken, 2002).

\subsection{Evaluation parameters}

\subsubsection{Water stress in the effective roots zone of cucumber plant and Soil Moisture Content}

Soil moisture was measured in effective roots zone before and after irrigation and the field capacity and wilting point were taken as evaluation lines in consideration as an evaluation parameter 
for exposure range of the plants to water stress "WS" (Abdelraouf et al., 2020 a). Measurements were taken at soil depths at mid-growth stage. Soil moisture was measured by profile probe device.

\subsubsection{Water application efficiency:}

Application efficiency of irrigation water $\left(\mathrm{AE}_{\mathrm{IW}}\right)$ is the actual storage of water in the root zone to the water applied to the field. $\mathrm{AE}_{\mathrm{IW}}$ was calculated using equation 2 :

$\mathrm{AE}_{\mathrm{IW}}=\mathrm{Ds} / \mathrm{Da}$

Where $\mathrm{AE}_{\mathrm{IW}}$ is the application efficiency of irrigation water, \%, Da is the depth of applied water $(\mathrm{mm})$, Ds is the depth of stored water in the root zone, mm by equation 3 .

$$
\text { Ds }=(\theta 1-\theta 2) * d \text {. }
$$

Where:, $d$ is the stored water in the soil layer depth $(\mathrm{mm}), \theta 1$ is the average of soil moisture content after irrigation $(\mathrm{g} / \mathrm{g})$ in the root zone, $\theta 2$ is the average of soil moisture content before irrigation $(\mathrm{g} / \mathrm{g})$ in the root zone at peak water requirements

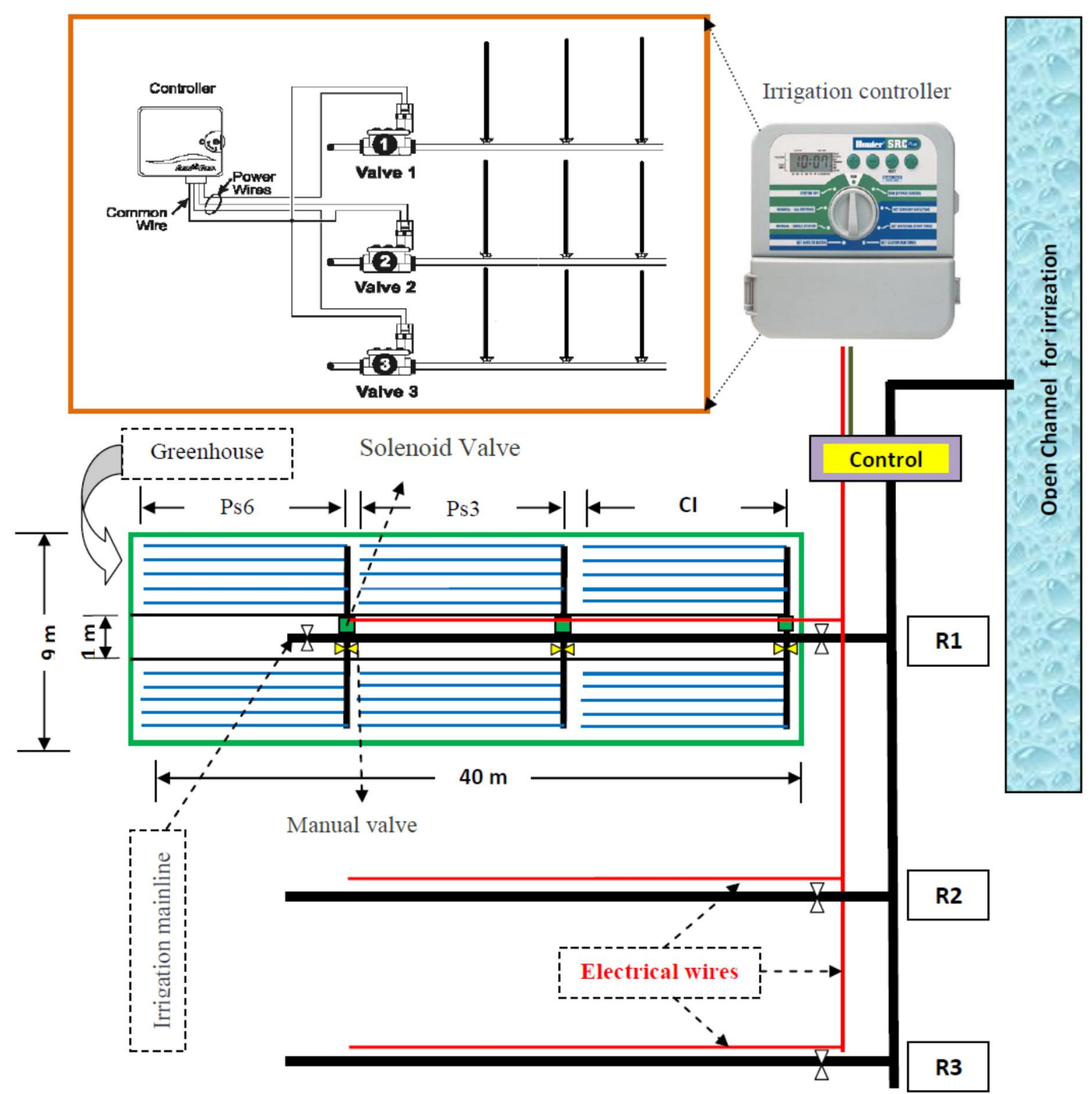

Fig. 1: Layout of the experimental design

CI: Continuous Irrigation (control); Ps6: 6 pulses/day, Ps3: 3 pulses/day. 


\subsection{Leaves area of cucumber plant}

Leaves area, $\mathrm{cm}^{2}$ after 90 days from transplanting for cucumber plants grown under greenhouse conditions.

The leaf area was determined by the CI-203 Handheld Laser Leaf Area Meter. Measurements were made easily by sweeping the scanner over a leaf to yield seven different parameters: area, width, length, perimeter, shape factor, aspect ratio, and void count.

\subsection{Chlorophyll content of cucumber plant:}

Total Chlorophyll, SPAD after 90 days from transplanting for cucumber plants grown under greenhouse conditions.

\subsection{Total yield of cucumber:}

At harvest time of cucumber, total weight of fruits in each treatment were recorded by harvesting cucumber as $\mathrm{Kg}$ per $1 \mathrm{~m}^{2}$ were calculated, fruits twice weekly and then the total yield as ton/hectare was calculated.

2.9. Water productivity of cucumber "WP cucumber" was calculated according to James (1988) by equation (4) as follows:

$\mathrm{WP}_{\text {cucumber }}=\mathrm{Ey} / \mathrm{Ir}$

Where: $\mathrm{WP}_{\text {cucumber }}$ is water productivity of $\mathrm{f}_{\text {cucumber }}\left(\mathrm{kg}\right.$ cucumber $/ \mathrm{m}^{3}$ irrigation water $)$, Ey is the economical yield ( $\mathrm{kg}_{\text {cucumber }} /$ hectare/season); Ir is the applied amount of irrigation water $\left(\mathrm{m}^{3}\right.$ irrigation water $/$ hectare/season).

\subsection{Statistical analysis}

Combined analysis of data for the two studied growing seasons was carried out according to Snedecor and Cochran (1989) and the values of least significant differences (L.S.D. at $5 \%$ level) were calculated to compare the means of the different treatments.

\section{Results and Discussion}

\subsection{Soil Moisture content Inside Root Zone of Cucumber Plant}

Figure (2) indicated that, there was a significant effect for pulse irrigation technique on the increasing of soil moisture content within the root zone "SMC". SMC values were increased by increasing number of irrigation pulses before irrigation. The highest values of SMC were under 6 pulses for irrigation per day and the lowest values were at continuous irrigation "Ps1" with both manual and automatic irrigation control. It was clear from above data that, there are differences in the soil moisture content in the root zone after applying pulse technique compared with continuous drip irrigation, this due to increasing number of irrigation pulses per day cause increasing in water movement in horizontal direction than vertical direction and this led to enhancement in soil moisture distribution inside root zone. These results are agreement with those obtained by Segal et al., (2000), Helen (2007), Shock et al. (2006), Bouma et al. (2003) Eric et al. (2004), and Zin El-Abedin, (2006).

\subsection{Water application efficiency}

The water application efficiency (\%) was measured under two irrigation scheduling controlling methods, manual and automatic irrigation with 6 pulses, 3 pulses and 1 pulse irrigation treatments, for the two growing seasons. Figure (3) shows the water application efficiency for manual and automatic irrigation under pulse drip irrigation treatments, for two seasons. The water application efficiency under automatic irrigation is higher than the manual irrigation for the two growing seasons. The highest water application efficiency values were 97 and $96.3 \%$ under automatic irrigation and 6 pulses/day treatment and the lowest values were 89 and $86 \%$ under manual irrigation and 1 pulse/day, for the two growing seasons (2017/2018 and 2018/2019), respectively. Also, there was a significant effect under the pulse irrigation treatments. However, the highest water application efficiency was under 6 pulses/day followed by 3 pulses/day and the lowest value was under 1 pulse/day with manual and automatic irrigation for two seasons. 


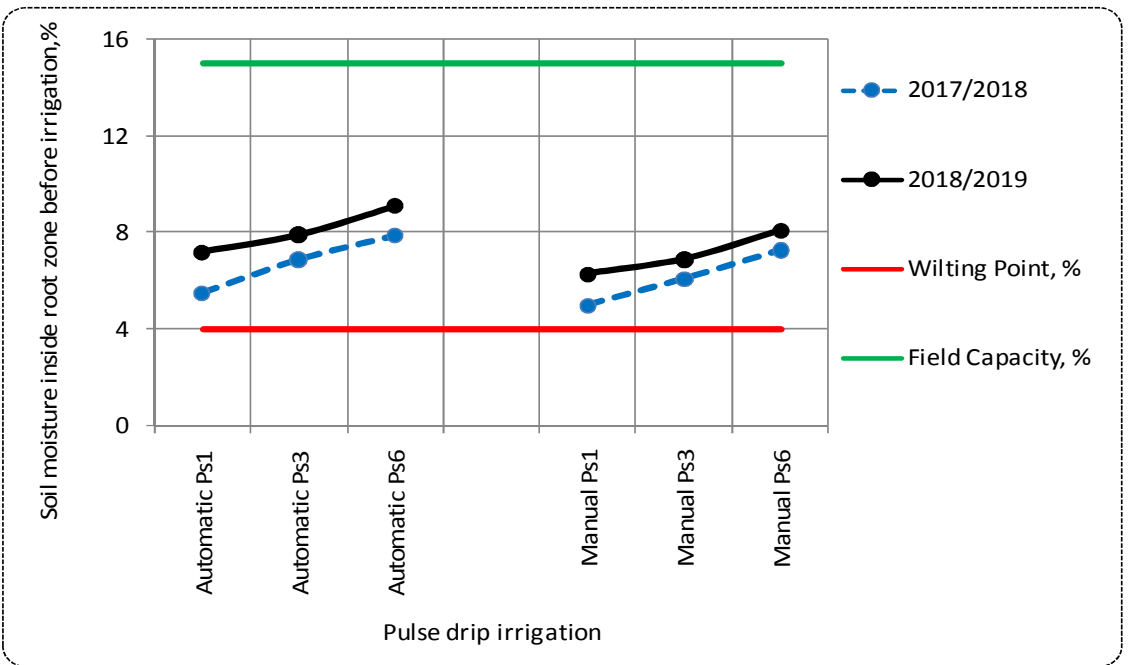

Fig. 2: Effect of manual and automatic irrigation with pulse drip irrigation on the increasing of moisture content within the root zone (Ps1: continuous irrigation (control), Ps3: 3 pulses/day and Ps6: 6 pulses/day).

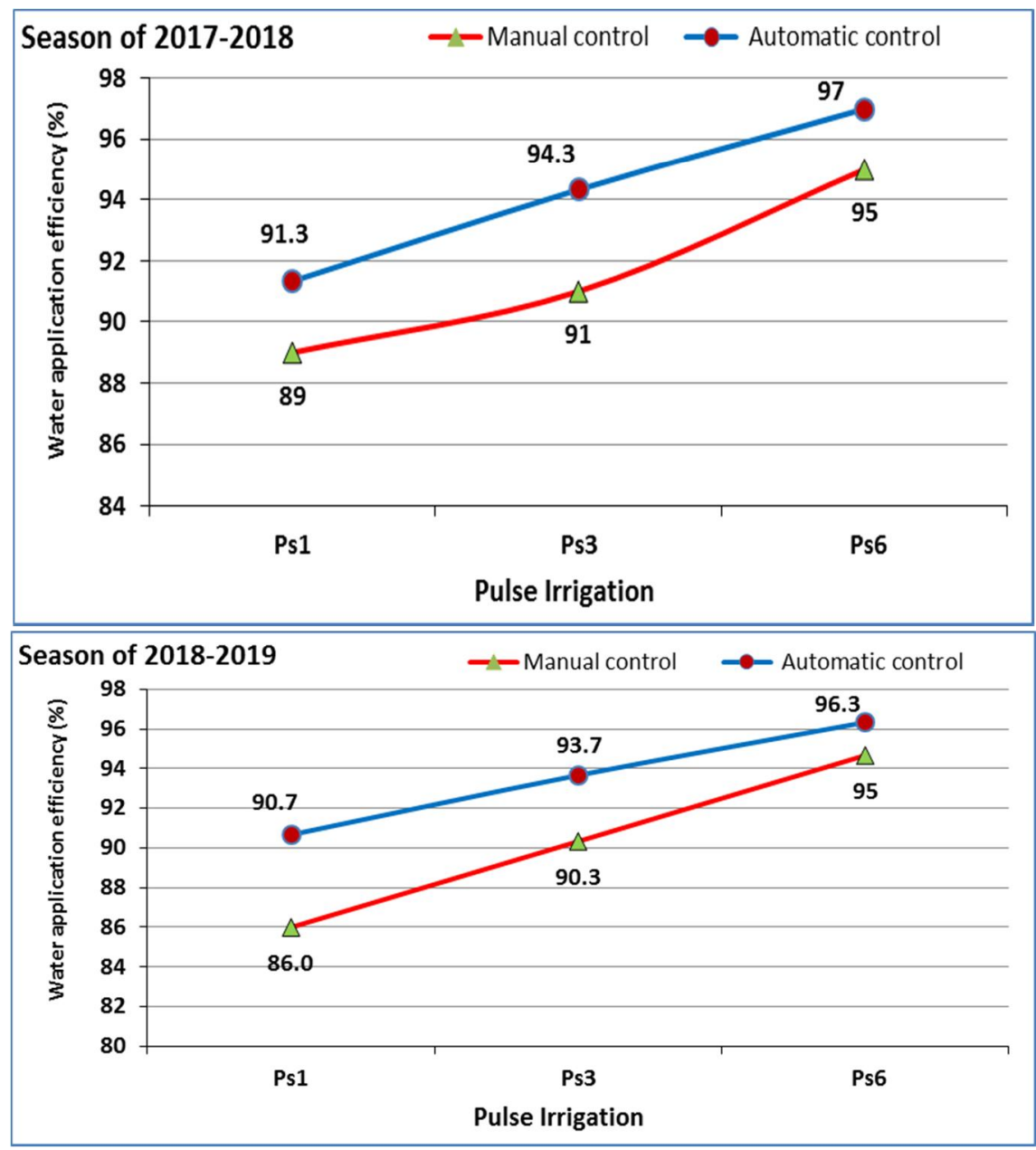

Fig. 3: Water application efficiency under manual and automatic irrigation with different pulses drip irrigation for two seasons. (Ps1: continuous irrigation (control), Ps3: 3 pulses/day and Ps6: 6 pulses/day).

As shown in Figure (4) the cucumber crop was taken the same water requirements under irrigation scheduling methods and all pulses irrigation treatments, $\left(6000\right.$ and $6100 \mathrm{~m}^{3}$ ha $\left.{ }^{-1}\right)$ for the first 
and the second seasons, respectively. The water application efficiency was higher than under the automatic irrigation compared to the manual irrigation.

The values of water application efficiency under automatic irrigation with 6 pulses, 3 pulses and 1 pulse /day were (97, 94.3 and 91.3\%) and $(96.3,93.7$ and $90.7 \%)$ for the two seasons, respectively. In general, the applied of pulse irrigation system gave regularity in water distribution, which leads to a high water application efficiency (Vázquez et al., 2006, Zotarelli et al., 2009).
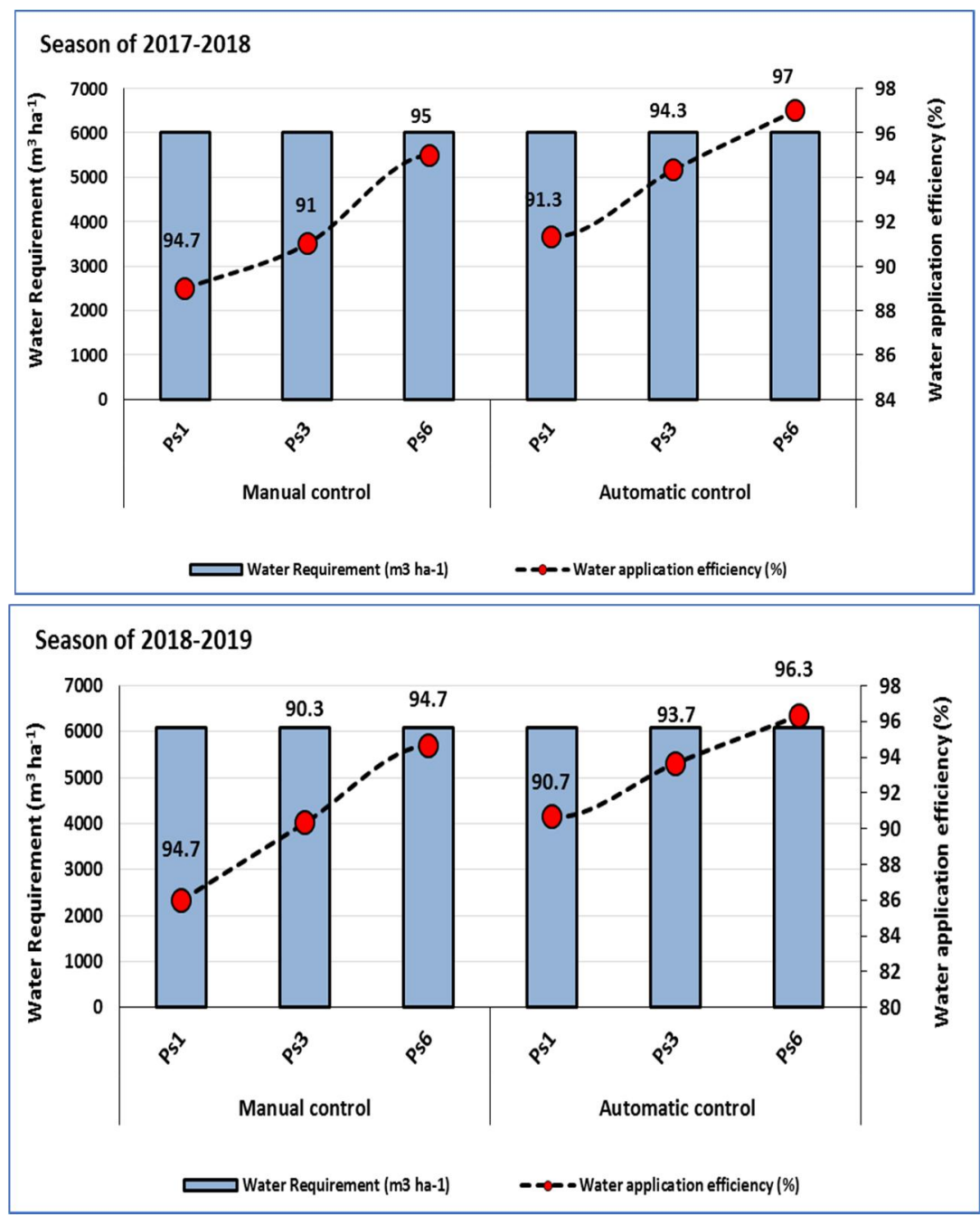

Fig. 4: Water application efficiency and water requirements under manual and automatic irrigation with different pulses drip irrigation for two seasons. (Ps1: continuous irrigation (control), Ps3: 3 pulses/day and Ps6: 6 pulses/day).

\subsection{Leaves Area and Total Chlorophyll of Cucumber crop}

\subsubsection{Irrigation scheduling controlling methods}

With regard to statistical analysis Table (3) presented the informative data about irrigation scheduling controlling methods. Generally to achieve a good plant stand (growth characteristics), automatic irrigation was applied. There was a significant difference between applying of automatic control for scheduling irrigation and manual control for scheduling irrigation. As Table (3) shown the leaves area of automatic irrigation values were higher by (28.74 and 26.17\%) compared with manual control system for the first and the second seasons, respectively. The automatic control significantly surpassed the manual control in total Chlorophyll by (30.7 and 30.1\%) for the first and the second seasons, respectively. 


\subsubsection{Pulse drip irrigation}

The results in Table (3) mention that pulse irrigation had a significant effect on leaf area and total chlorophyll of cucumber crop. For the pulse irrigation treatments, the highest leaf area and total chlorophyll values were under 6 pulses/day followed by 3 pulses/day the lowest values were under 1 pulse/day for the two growing seasons.

\subsubsection{Interaction}

Table (3) shows the result of the interaction between irrigation scheduling controlling methods and Pulse drip irrigation of the two growing seasons. Significant variations were shown in the leaves area and the total chlorophyll. Generally, the highest values of leaves area were 14209.3 and $13104 \mathrm{~cm}^{2}$ by using automatic irrigation and 6 pulses/day for the two growing seasons, respectively. Also, the similar trend was obtained for the total chlorophyll under the automatic irrigation and 6 pulses/day treatment.

Therefore, it can be recommended that, the use of automatic scheduling irrigation and pulse irrigation are more beneficial in maximizing the leaves area and the total chlorophyll of the cucumber crop under greenhouses condition.

Table 3: Effect of irrigation scheduling controlling methods and pulse irrigation on the leaves area and total chlorophyll of cucumber crop.

\begin{tabular}{|c|c|c|c|c|c|}
\hline \multirow{2}{*}{ SI } & \multirow{2}{*}{$\begin{array}{l}\text { Pulse drip } \\
\text { irrigation }\end{array}$} & \multicolumn{2}{|c|}{ Leaves Area $\left(\mathrm{cm}^{2}\right)$} & \multicolumn{2}{|c|}{ Total Chlorophyll } \\
\hline & & 2017-2018 & 2018-2019 & 2017-2018 & 2018-2019 \\
\hline \multicolumn{6}{|c|}{$\begin{array}{l}\text { Effect of irrigation scheduling controlling methods on the leaves area and total chlorophyll content of } \\
\text { cucumber plant }\end{array}$} \\
\hline Manual & & 9479.5 & 8879.7 & 34.2 & 31.9 \\
\hline Automatic & & 12204.2 & 11203.7 & 44.7 & 41.5 \\
\hline LSD at 5\% & & 646.04 & 598.36 & 1.19 & 1.11 \\
\hline \multicolumn{6}{|c|}{ Effect of pulse irrigation on leaves area and total chlorophyll of cucumber plant } \\
\hline & Ps1 & 9385.83 & 8579.1 & 32.3 & 31.5 \\
\hline & Ps3 & 10676.3 & 10052.3 & 41.1 & 36.3 \\
\hline & Ps6 & 12463.5 & 11493.8 & 44.9 & 42.3 \\
\hline LSD at 5\% & & 301.33 & 279.09 & 1.46 & 1.36 \\
\hline \multicolumn{6}{|c|}{$\begin{array}{l}\text { Effect of interaction between irrigation scheduling controlling methods and pulse irrigation on leaves } \\
\text { area and total chlorophyll of cucumber plant }\end{array}$} \\
\hline & Ps1 & 8570.0 & 7903.3 & 29.2 & 27.4 \\
\hline \multirow[t]{3}{*}{ Manual } & Ps3 & 9151.0 & 8852.3 & 33.9 & 31.2 \\
\hline & Ps6 & 10717.6 & 9883.6 & 39.4 & 37.1 \\
\hline & Ps1 & 10201.6 & 9255.0 & 35.4 & 35.5 \\
\hline \multirow[t]{2}{*}{ Automatic } & Ps3 & 12201.6 & 11252.3 & 48.4 & 41.5 \\
\hline & Ps6 & 14209.3 & 13104.0 & 50.4 & 47.4 \\
\hline LSD at 5\% & & 426.15 & 394.7 & 2.07 & 1.92 \\
\hline
\end{tabular}

*Ps1: continuous irrigation/day (control), Ps3: 3 pulses/day and Ps6: 6 pulses/day

\subsection{Total Yield of Cucumber}

\subsubsection{Irrigation scheduling controlling methods}

Table (4) presented the total cucumber yield under irrigation scheduling controlling methods. There was a significant effect of the yield under automatic scheduling irrigation for the two growing seasons.

\subsubsection{Pulse drip irrigation}

The results in Table (4) mention that pulse irrigation had a significant effect on the yield of cucumber crop. For the pulse irrigation treatments, the highest yield values were under 6 pulses/day followed by 3 pulses/day the lowest values were under 1 pulse/day for the two growing seasons.

\subsubsection{Interaction}

Concerning of total fresh yield/ha data illustrated in Figure (5) and Table (4) showed that the effect of irrigation scheduling controlling methods and pulse irrigation on fresh yield/ha of cucumber. 
Overall the highest values were (453.8 and 152.1 ton $\mathrm{ha}^{-1}$ ) under automatic control of scheduling irrigation with 6 pulses/day, for the two growing seasons, respectively. The automatic control of scheduling irrigation gave the superior in fresh cucumber yield $\left(153.8,143.53\right.$ and 126.9 ton ha $\left.{ }^{-1}\right)$ for the first season, and $\left(152.1,14.7\right.$ and 123.4 ton $\left.\mathrm{ha}^{-1}\right)$ for the second season, with pulse irrigation 6 pulses, 3 pulses and 1 pulse /day treatments, respectively. Followed by manual control of scheduling irrigation $\left(135.67,125.57\right.$ and 116.13 ton ha $\left.{ }^{-1}\right)$ for the first season, and $\left(134.1,122,9\right.$ and 109.2 ton ha $\left.{ }^{-1}\right)$ for the second season, with pulse irrigation 6 pulses, 3 pulses and 1 pulse /day treatments, respectively. While 1 pulse /day treatment, came later (116.13 and 126.9 ton ha $\left.^{-1}\right),\left(109.2\right.$ and 123.4 ton ha $^{-1}$ ) under manual and automatic controlling methods for the two seasons, respectively. This might concluded that, irrigated by 6 pulses/day under automatic control induced the same effect on yield of cucumber crop. There is a high yield by applying pulse drip irrigation with more frequent irrigation (Dukes et al., 2003, Segal et al., 2006).
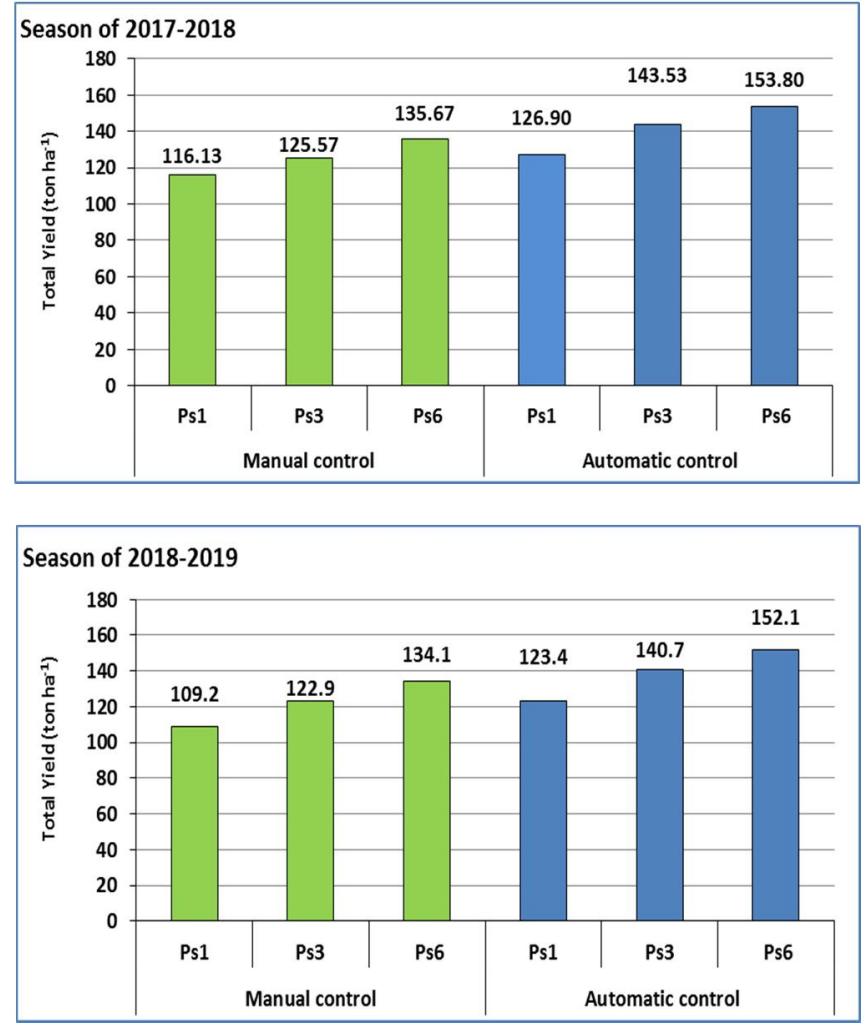

Fig. 5: Cucumber yield under manual and automatic irrigation, different pulse drip irrigation for two seasons. (Ps1: continuous irrigation (control), Ps3: 3 pulses/day and Ps6: 6 pulses/day).

\subsection{Water productivity of cucumber}

\subsubsection{Irrigation scheduling controlling methods}

Table (4) presented there are same trend between yield and water productivity of cucumber crop under irrigation scheduling controlling methods.

\subsubsection{Pulse drip irrigation}

Table (4) mention that there is clearly a similarity between the results of yield and water productivity under Pulse drip irrigation treatments. The highest water productivity values were under 6 pulses/day followed by 3 pulses/day the lowest values were under 1 pulse/day for the two growing seasons.

\subsubsection{Interaction}

The same trend is found between yield and water productivity of cucumber crop. Figure (6) and Table (4) presented the effect of irrigation scheduling controlling methods and pulse irrigation on water productivity of cucumber. Generally the highest values were $\left(25.67\right.$ and $\left.24.9 \mathrm{~kg} \mathrm{~m}^{-3}\right)$ under automatic 
control of scheduling irrigation with 6 pulses/day, for the two growing seasons, respectively. The automatic control scheduling irrigation gave the superior in water productivity $(25.67,25.63$ and 21.17 $\left.\mathrm{kg} \mathrm{m}^{-3}\right)$ for the first season, and $\left(24.9,23.07\right.$ and $\left.20.2 \mathrm{~kg} \mathrm{~m}^{-3}\right)$ for the second season, with pulse irrigation 6 pulses, 3 pulses and 1 pulse /day treatments, respectively.
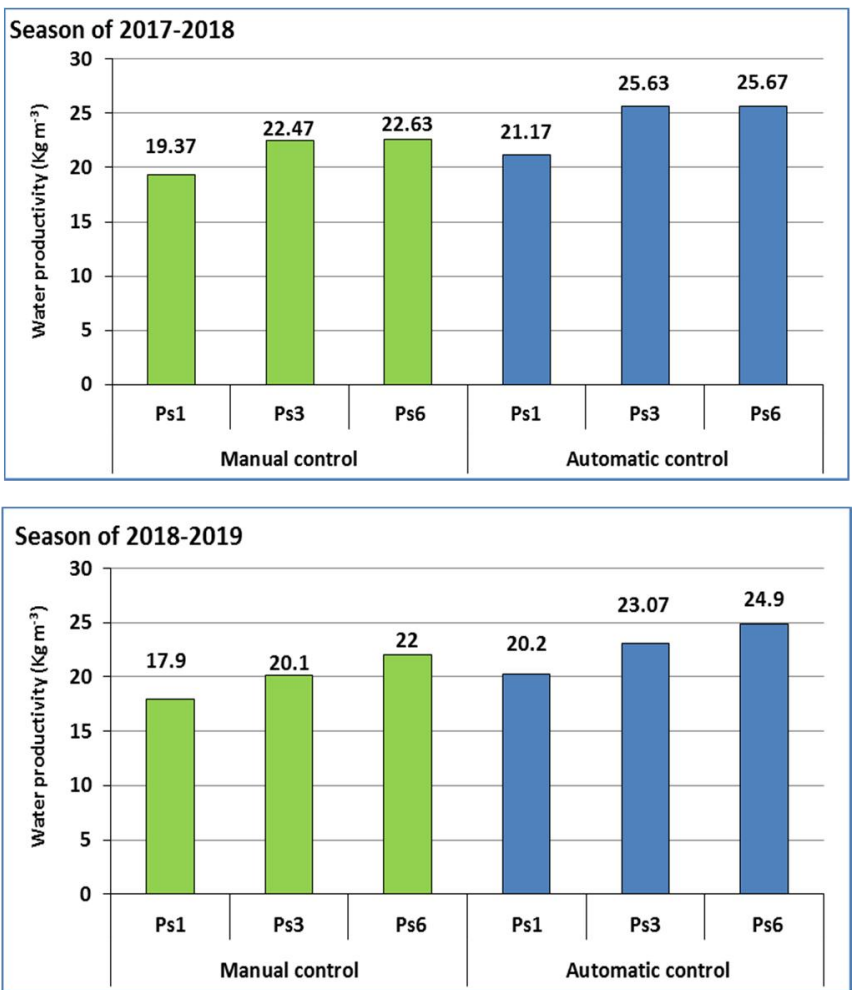

Fig. 6: Water productivity of cucumber under manual and automatic irrigation, different pulse drip irrigation for two seasons. (Ps1: continuous irrigation (control), Ps3: 3 pulses/day and Ps6: 6 pulses/day).

Table 4: Effect of irrigation scheduling controlling methods and pulse irrigation on the yield and water productivity of cucumber crop.

\begin{tabular}{|c|c|c|c|c|c|}
\hline \multirow{2}{*}{ SI } & \multirow{2}{*}{ Pulse drip irrigation } & \multicolumn{2}{|c|}{ Yield $\left(\right.$ ton $\left.\mathrm{ha}^{-1}\right)$} & \multicolumn{2}{|c|}{ Water productivity $\left(\mathrm{kg} \mathrm{m}^{-3}\right)$} \\
\hline & & 2017-2018 & 2018-2019 & 2017-2018 & 2018-2019 \\
\hline \multicolumn{6}{|c|}{$\begin{array}{l}\text { Effect of irrigation scheduling controlling methods on the leaves area and total chlorophyll content of } \\
\text { cucumber plant }\end{array}$} \\
\hline Manual & & 125.79 & 122.07 & 21.49 & 20.01 \\
\hline Automatic & & 141.41 & 138.72 & 24.16 & 22.73 \\
\hline LSD at $5 \%$ & & 2.34 & 2.28 & 0.43 & 0.4 \\
\hline \multicolumn{6}{|c|}{ Effect of pulse irrigation on leaves area and total chlorophyll of cucumber plant } \\
\hline & Ps1 & 121.52 & 116.27 & 20.27 & 19.07 \\
\hline & Ps3 & 134.55 & 131.80 & 24.05 & 21.60 \\
\hline & Ps6 & 144.73 & 143.12 & 24.15 & 23.45 \\
\hline LSD at $5 \%$ & & 2.87 & 2.8 & 0.53 & 0.5 \\
\hline \multicolumn{6}{|c|}{$\begin{array}{l}\text { Effect of interaction between irrigation scheduling controlling methods and pulse irrigation on leaves } \\
\text { area and total chlorophyll of cucumber plant }\end{array}$} \\
\hline & Ps1 & 116.13 & 109.2 & 19.37 & 17.9 \\
\hline \multirow[t]{2}{*}{ Manual } & Ps3 & 125.57 & 122.9 & 22.47 & 20.1 \\
\hline & Ps6 & 135.67 & 134.1 & 22.63 & 22 \\
\hline \multirow{3}{*}{ Automatic } & Ps1 & 126.90 & 123.4 & 21.17 & 20.2 \\
\hline & Ps3 & 143.53 & 140.7 & 25.63 & 23.07 \\
\hline & Ps6 & 153.80 & 152.1 & 25.67 & 24.9 \\
\hline LSD at $5 \%$ & & 4.06 & 3.96 & 0.75 & 0.7 \\
\hline
\end{tabular}


While the manual control of scheduling irrigation gave the lower results of water productivity $\left(22.63,22.47\right.$ and $\left.19.37 \mathrm{~kg} \mathrm{~m}^{-3}\right)$ for the first season, and $\left(22,20.1\right.$ and $\left.17.9 \mathrm{~kg} \mathrm{~m}^{-3}\right)$ for the second season, with pulse irrigation 6 pulses, 3 pulses and 1 pulse /day treatments, respectively. This might concluded that, irrigated by 6 pulses/day under automatic control induced the same effect on water productivity of cucumber crop. The Data of yield and water productivity noticed that the effect induced by water uniformity and good horizontal distribution of water under automatic control of scheduling irrigation and 6 pulses/day, were more than those caused under manual control of scheduling irrigation, 3 pulses and 1 pulse /day.

The previous results indicate that the automatic control system led to uniformity in irrigation of the cucumber crop, increased water production (WP), and gave better irrigation scheduling which was found consistent with those obtained from (Dukes et al., 2007, Venkatapur and Nikitha, 2017, Segal et al., 2006). This data is in agreement with the last research papers (Ertek et al., 2006).

Finally, the best irrigation scheduling method is especially important on sandy soils, because sandy soils require a balance in water application efficiency and low deep percolation to provide water without decreasing the yield (Lozano et al., 2020 and Smarsly, 2013).

\section{Conclusion}

The previous results noticed that, the use of automatic pulse drip irrigation has improved soil moisture content within the root zone, application efficiency, yield and water productivity of cucumber under greenhouses conditions. Overall the higher values of soil moisture content, water application efficiency, yield and water productivity were obtained under the automatic control compared to manual control of scheduling irrigation under all pulse irrigation treatments ( 6 pulses/day, 3 pulses and 1 pulse /day). In general, there was a significant effect of all measured field results under the automatic control of scheduling irrigation and 6 pulses/day. This effect caused by water uniformity and good horizontal distribution of water under automatic control of scheduling irrigation and 6 pulses/day, were more than those caused under manual control of scheduling irrigation, 3 pulses and 1 pulse /day. Therefore, it can be recommended that, the use of automatic scheduling irrigation and pulse irrigation are more beneficial in maximizing the water application efficiency and yield and water productivity of the cucumber crop under greenhouses condition.

\section{References}

Abdelraouf, R.E. and S.F. El Habbasha, 2014. Wheat production in the arid regions by using drip irrigation system. International Journal of Advanced Research, 2: 84-96.

Abdelraouf, R.E., H.G. Ghanem, N.A. Bukhari, and M. El-Zaidy, 2020. Field and Modeling Study on Manual and Automatic Irrigation Scheduling under Deficit Irrigation of Greenhouse Cucumber. Sustainability, 12(23): 9819.

Abdelraouf, R.E., M. El-Shawadfy, A. Fadl, A. Hashem and B.M.M. Bakr, 2020 a. Effect of deficit irrigation strategies and organic mulching on yield, water productivity and fruit quality of navel orange under arid regions conditions. Plant Archives, 20 (1):3505-3518.

Allen, R.G., L.S. Pereira, M. Smith, D. Raes, and J.L. Wright, 2005. FAO-56 dual crop coefficient method for estimating evaporation from soil and application extensions. Journal of irrigation and drainage engineering, 131(1): 2-13.

Bouma, J.R., B. Brown, and S.C. Rao, 2003. Movement of water: Basics of soil water relationships part III. UFAS extension fact sheet SL-39.

Dukes, M.D., R. Muñoz-Carpena, L. Zotarelli, J. Icerman, and J.M. Scholberg, 2007. Soil moisturebased irrigation control to conserve water and nutrients under drip irrigated vegetable production. Jornada de Investigación en la Zona no Saturada, 8: 229-236.

Dukes, M.D., E.H. Simonne, W.E. Davis, D.W. Studstill, and R. Hochmuth, 2003. May. Effect of sensor-based high frequency irrigation on bell pepper yield and water use. In Proceedings of 2nd International Conference on Irrigation and Drainage, May, 12-15.

El-Shafie, A.F., M.A. Marwa, and O.M. Dewedar, 2018. Hydraulic Performance Analysis of Flexible Gated Pipe Irrigation Technique Using GPIMOD Model. Asian Journal of Crop Science, 10(4): 180-189. 
Eric, S., S. David, and H. Robert, 2004. To pulse or not to pulse drip irrigation that is the question UF/IFAS - HoRTICULTURAL SCIENCES DEPARTMENT. Florida, USA NFREC-SV-Vegetarian (04-05).

Ertek, A., S. Şensoy, I. Gedik, and C. Küçükyumuk, 2006. Irrigation scheduling based on pan evaporation values for cucumber (Cucumis sativus L.) grown under field conditions. Agricultural water management, 81(1-2): 159-172.

Helen, R., 2007. Citrus Irrigation. Department of Agriculture and Food, Waroona. State of Western Australia. www. Agric .wa .gov.au

Hou, X.Y., F.X. Wang, J.J. Han, S.Z. Kang, and S.H. Fena, 2010. Duration of plastic mulch for potato growth under drip irrigation in an arid region of northwest China. Agric. For. Meteorol. 150: 115121. https://doi.org/10.3390/su12239819.

Jalota, S.K., and S.S., Prihar, 1990. Bare-soil evaporation in relation to tillage. In: Steward, B.A. (Ed.), Advances in Soil Science. Spring-Verlag, New York, 187-216.

Lozano, D., N. Ruiz, R. Baeza, J.I. Contreras, and P. Gavilán, 2020. Effect of Pulse Drip Irrigation Duration on Water Distribution Uniformity. Water, 12(8): 2276. https://doi.org/10.3390/w12082276.

Luquet, D., A. Vidal, M. Smith, and J. Dauzat, 2005. More crop per drop': how to make it acceptable for farmers?. Agricultural Water Management, 76(2): 108-119.

Maller, A., R. Rezende, P.S.L.D. Freitas, C.C. Seron, and T.L. Hachmann, 2019. Moisture in the soil profile with water applications using pulse drip irrigation. Revista Ciência Agronômica, 50(2): 234-241.

Marwa, M.A., R.E. Abdelraouf, S.A. Wahba, K.F. El-Bagouri, and A.G. El-Gindy, 2017. Scheduling irrigation using automatic tensiometers for pea crop. Agricultural Engineering International: CIGR Journal, 19(Special Issue): 174-183.

Sarkar, S., M. Pramanik, and S.B. Goswami, 2007. Soil temperature, water use and yield of yellow sarson (Brassica napus, var glauca) in relation to tillage intensity and mulch management under rainfed lowland ecosystem in eastern India. Soil Tillage Res. 93: 94-101.

Savva, A.P. and K. Frenken, 2002. Irrigation Manual, Planning, development monitoring and evaluation of irrigated agriculture with farmer participation. Volume IV, FAO, SAFR, Harare, 2002.Available from: http://www.fao.org/docrep/pdf/010/ai596e/ai596e.pdf [Accessed 17 October 2020]

Segal, E., A. Ben-Gal, and U. Shani, 2006. Root water uptake efficiency under ultra-high irrigation frequency. Plant and Soil, 282(1): 333-341.

Segal, E., A. Ben-Gal, and U. Shani, 2000. Water availability and yield response to high-frequency micro-irrigation in sunflowers. 6th International Micro-irrigation Congress. Micro-irrigation Technology for Developing Agriculture'. South Africa, 22 - 27 October E-mail alonbengal@rd.ardom.co.il

Shock, C.C., R.J. Flock, E.P. Eldredge, A.B. Pereira, and L.B. Jensen, 2006. Successful Potato Irrigation Scheduling. Oregon State University Extension Service publication EM 8911-E. Available online at http:// extension. oregonstate. Edu /catalog/ pdf/em/ em8911-e.pdf

Smarsly, K., 2013. August. Agricultural ecosystem monitoring based on autonomous sensor systems. In 2013 Second International Conference on Agro-Geoinformatics (Agro-Geoinformatics) (pp. 402-407). IEEE.

Snedecor, G.W. and W.G. Cochran, 1989. Statistical Methods, eight edition. Iowa state University press, Ames, Iowa, 1191.

Vázquez, N., A. Pardo, M.L. Suso, and M. Quemada, 2006. Drainage and nitrate leaching under processing tomato growth with drip irrigation and plastic mulching. Agriculture, ecosystems \& environment, 112(4): 313-323.

Venkatapur, R. and S. Nikitha, 2017. Review on Closed Loop Automated Irrigation System. The Asian Review of Civil Engineering, 6(1): 9-14.

Wahba, S.A., A.M. El-Gindy, K.F. El-Bagouri, and M.A. Marwa, 2016. Response of green peas to Irrigation automatic scheduling and potassium fertigation. International Journal of ChemTech Research, 9(3): 228-237. 
Zamora, V.R.O., M.M. Da Silva, G.F. da Silva, J.A. Santos Júnior, D. Menezes, and S.M.D. Menezes, 2019. Pulse drip irrigation and fertigation water depths in the water relations of coriander. Horticultura Brasileira, 37(1): 22-28.

Zin El-Abedin, T.K., 2006. Effect of pulse drip irrigation on soil moisture distribution and maize production in clay soil. The $14^{\text {th }}$ Annual Conference of Misr Society of Agr. Eng., 22 Nov., 1058 $-1076$

Zotarelli, L., J.M. Scholberg, M.D. Dukes, R. Muñoz-Carpena, and J. Icerman, 2009. Tomato yield, biomass accumulation, root distribution and irrigation water use efficiency on a sandy soil, as affected by nitrogen rate and irrigation scheduling. Agricultural water management, 96(1): 2334. 